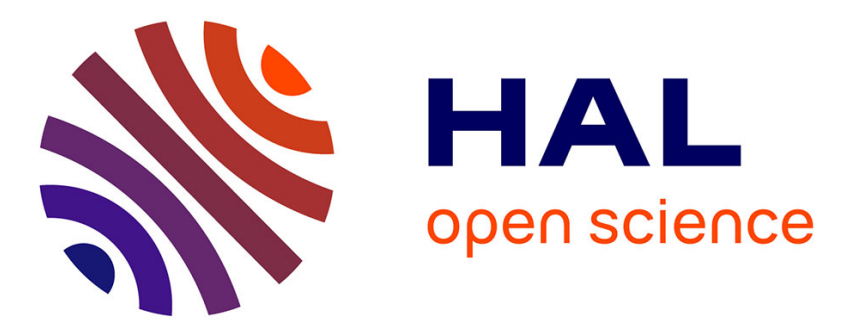

\title{
Experimental and numerical study of supercapacitors module with air-cooling
}

Ionut Voicu, Rania Rizk, Hasna Louahlia, Florin Bode, Hamid Gualous

\section{To cite this version:}

Ionut Voicu, Rania Rizk, Hasna Louahlia, Florin Bode, Hamid Gualous. Experimental and numerical study of supercapacitors module with air-cooling. Applied Thermal Engineering, 2019, 159, pp.113903. 10.1016/j.applthermaleng.2019.113903 . hal-02163508

\section{HAL Id: hal-02163508}

\section{https://hal-normandie-univ.archives-ouvertes.fr/hal-02163508}

Submitted on 25 Oct 2021

HAL is a multi-disciplinary open access archive for the deposit and dissemination of scientific research documents, whether they are published or not. The documents may come from teaching and research institutions in France or abroad, or from public or private research centers.
L'archive ouverte pluridisciplinaire $\mathbf{H A L}$, est destinée au dépôt et à la diffusion de documents scientifiques de niveau recherche, publiés ou non, émanant des établissements d'enseignement et de recherche français ou étrangers, des laboratoires publics ou privés.

\section{다)(1) $(5$}

Distributed under a Creative Commons Attribution - NonCommerciall 4.0 International 


\section{Experimental and numerical study of supercapacitors module with air-}

\section{cooling}

Ionut VOICU ${ }^{\mathrm{a}}$, Rania RIZK ${ }^{\mathrm{a}}$, Hasna LOUAHLIA ${ }^{\mathrm{a}}$, Florin BODE ${ }^{\mathrm{b}, \mathrm{c}}$, Hamid GUALOUS ${ }^{\mathrm{a}}$

${ }^{a}$ NORMANDIE UNIV, UNICAEN, LUSAC, 14000 Caen, France

${ }^{\mathrm{b}}$ CAMBI, Technical University of Civil Engineering in Bucharest, Romania

${ }^{c}$ Technical University of Cluj-Napoca, Mechanical Engineering Department, Cluj-Napoca, Romania

\section{Highlights}

- The thermal management of staggered supercapacitor stack is studied

- The surface temperatures are measured for natural and forced convection

- The numerical model enables to predict the temperature field for forced convection

- The thermal behaviour of the module operating at high current rates is investigated

- The risk of overheating is predicted for steady state and transient regime

\section{Keywords}

Supercapacitor, thermal management, staggered arrangement, experimentation, modelling, air-cooling. 


\section{Abstract}

This paper deals with the thermal management of a supercapacitor module with air-cooling. An experimental test bench is used for thermal characterization of nine supercapacitors assembled in a module with a staggered arrangement by measuring surface temperatures for several current rates (up to $70 \mathrm{~A}$ ) and inlet air velocities between zero and $0.6 \mathrm{~m} \mathrm{~s}^{-1}$. The experimental results obtained in natural convection make it possible to estimate the maximal relative surface temperature at $84 \mathrm{~A}$ (the maximum current rate) between $26.6{ }^{\circ} \mathrm{C}$ and $30{ }^{\circ} \mathrm{C}$. This result shows that overheating can occur for high current rates and air temperature higher than $30^{\circ} \mathrm{C}$, so a ventilation cooling system can be useful. A numerical study is also undertaken for forced convection regime (inlet airflow between $0.2 \mathrm{~m} \mathrm{~s}^{-1}$ and $0.8 \mathrm{~m} \mathrm{~s}^{-1}$ ) and 70 A current rate. The numerical results are in good agreement with the experimental results. The mean deviation between experimental and numerical relative temperatures is $19.8 \%$ for steady state regime and $17.5 \%$ for transient regime comparison. Therefore, numerical simulations are used to estimate the temperature distribution within the supercapacitors. At steady state regime, the difference between maximal internal temperature and maximal surface temperature is between $2.5{ }^{\circ} \mathrm{C}$ and $3{ }^{\circ} \mathrm{C}$. At steady state regime, the maximum temperature is located near the axis and for transient regime, it is located inside the active zone. The evolution of temperatures for maximal current rate and $40{ }^{\circ} \mathrm{C}$ inlet air temperature is also studied numerically. Overheating can occur for steady state regime for a velocity less than $0.15 \mathrm{~m} \mathrm{~s}^{-1}$. On the other hand, after four minutes' work the temperature of supercapacitors remains lower than $42.5^{\circ} \mathrm{C}$ and is very slightly influenced by the velocity of air. 


\section{Introduction}

Supercapacitors, also referred to as ultracapacitors or electrochemical double layer capacitors, are power-storage devices that can be charged and discharged in seconds and can withstand hundreds of thousands of cycles [1]. Their storage and power performances are rated between those of batteries and capacitors. Their available power is higher than that of batteries and lower than that of capacitors. However, their available energy is higher than that of capacitors and lower than that of batteries. This makes them perfect to recover from quick power fluctuations and to supply quick power peak demand [1,2] ; or for pulse power applications [1]. Supercapacitors are usually used in energy management system for batteries [3-5] and fuel cells [6] as handy alternative to improve the efficiency and performance of the main energy source. They are found in different applications [1,7] such as automotive [8], public transportation [9-11], isolated power generation systems [12] and renewable energy applications [13].

Many aspects of the supercapacitor performance are strongly affected by their operating temperature, including power, energy capability, reliability, cycle life and cost $[2,14]$. Even if the increase of temperature is considered as a beneficial factor by increasing the electrolyte conductivity, it is important to remember that the electrolyte is generally made of an organic solution in which the solvent starts evaporating at $20^{\circ} \mathrm{C}$. From this standpoint, the increase of electrolyte temperature leads to a loss of solvent [15]. In addition, the lifetime of supercapacitors decreases by half every $10{ }^{\circ} \mathrm{C}$ above $25{ }^{\circ} \mathrm{C}$ [16] and the temperature difference inside the module must remain below $5{ }^{\circ} \mathrm{C}$ for a full lifespan [10]. Supercapacitor equivalent serial resistances (ESR) which generate heat during charging can cause overheating [17]. Which makes thermal management necessary, especially in supercapacitor modules where the cells are closely packed, to maintain the pack with uniform temperature distribution or only small temperature variations within the pack. However, this adds additional volume, mass and cost, and reduces the energy density of the system [2]. 
Consequently, most of the time, supercapacitors are equipped with a cooling system when temperature may exceed approximately $65^{\circ} \mathrm{C}[18]$, which is usually the maximum operating temperature. On the other side, supercapacitors have an excellent low-temperature performance, even down to $-40^{\circ} \mathrm{C}[2]$, no heating system is required.

The cooling systems used for energy storage units, such as supercapacitors and batteries, are broadly classified into two categories [2,19,20]: active and passive. Generated heat is usually carried out by an airflow through forced convection. This simple active cooling system provides a compact structure and cost-effective feature $[2,21]$.

The supercapacitors used in modules are generally cylindrical in shape. Blowing air over the cylindrical bodies in a perpendicular direction can efficiently cool them [22]. This air-cooling system is also used for cylindrical batteries [23-26], and is commonly encountered in practice in heat transfer equipment such as condensers and evaporators of power plants, refrigerators, and air conditioners $[22,27]$.

Gualous et al. [28] and Frivaldsky et al. [29] studied the supercapacitor temperature evolution measured along the axial and radial directions, for several dynamic power levels and, particularly, the hot-spot (overheating) temperature that limits the device operation. The results show that temperature decreases along the radius. This variation is very low in axial direction, compared to that in radial direction. Over time, the supercapacitor temperature increases exponentially [28].

Berrueta et al. [30] studied a cooling system in which the air flow does not flow through the supercapacitor module but at the outside of a case used for enclosing it. Al Sakka et al. [18] investigated a module with in-line supercapacitor arrangement where neighbouring supercapacitors are touch one another. Hijazi et al. [31] used a staggered supercapacitor arrangement with one base in contact with the air-flow.

Recently, different staggered arrangements have been compared taking into account ventilation power, compactness of the stack and maximal temperature for each row of the 
stack [32]. This study proposes a model more accurate than the previous one [18,28-31]. It finely takes into account the different parameters like Joule effect, local variation of the convection heat transfer, the differences of thermal conductivity between the active and inactive zone, the variation of the thermal conductivity in the different directions of space in the active area, and the transient regime. On the other hand, this model is not validated experimentally on a real module of supercapacitors. For the validation, only experimental correlations existing in the literature for flow across tube banks are used.

For supercapacitors systems, modelling is always essential for design prediction, condition monitoring, and control synthesis. Since a model is, at best, a surrogate for real systems, the accuracy of which is subject to assumptions and requirements, it must be generated for a specific purpose [33] and compared with a real system. The present work is in keeping with a previous investigation [32] on the thermal performance of different transverse and longitudinal pitches in staggered arrangement of a supercapacitor module, and the choice of the module structure is based on its conclusions. The aim of this paper is to compare experimental and numerical results for the spatial arrangement with a maximum cooling performance and compactness in the previous numerical study [32]. It is expected that this work is useful for design and thermal management of supercapacitors stacks.

\section{Experimentation}

\subsection{Experimental setup}

The experimental setup is designed in order to study the thermal management of a supercapacitor module. For safety reasons, the supercapacitors cannot be charged and discharged at the maximum authorized current rate. The experiments are performed to find the different parameters needed to validate the model developed to predict the thermal behaviour of the module at high current rates. These parameters include the difference between the maximal surface temperature of supercapacitors stack and the temperature of inlet air, for different air velocities. 


\subsubsection{Supercapacitors module}

This study is carried on a heat exchanger composed of an air-cooled module of nine supercapacitors. The BCAP 1500 P270 K04 supercapacitors are used. They belong to the K2 series made by Maxwell Technologies and are based on active carbon technology and organic electrolyte. Some of the product specifications are presented in Table 1.

Table 1 Main characteristics of the BCAP 1500 P270 K04 supercapacitor [34]

\begin{tabular}{ccccccc}
\hline $\mathrm{ESR}(\mathrm{m} \Omega)$ & $\mathrm{I}_{\max }(\mathrm{A})$ & $\mathrm{T}_{\max }\left({ }^{\circ} \mathrm{C}\right)$ & $\mathrm{C}(\mathrm{F})$ & $\mathrm{L}(\mathrm{mm})$ & $\mathrm{D}(\mathrm{mm})$ & $\mathrm{D}(\mathrm{mm})$ \\
\hline 0.47 & 84 & 65 & 1500 & 85 & 60.4 & 14 \\
\hline
\end{tabular}

Space requirement, but also the power required to move airflow, are important parameters for supercapacitors cooling. At equal compactness level, the staggered arrangement has a higher heat transfer than the in-line one, especially in low range of $S_{L} / D$ [27]. In addition, the equilateral triangular arrangement of staggered supercapacitors needs lower ventilation power [22]. Previously, Voicu et al. [32] studied numerically five longitudinal rows of supercapacitors with this configuration for different compactness levels. They recommended an arrangement with a transversal pitch between two consecutive supercapacitors equal to 1.25 time the diameter. This arrangement is selected for this study too. Nine supercapacitors are assembled in a module as shown in Fig. 1. The longitudinal and transversal pitches are 65 $\mathrm{mm}$ and $75 \mathrm{~mm}$ respectively.

Thereafter, an investigation on the thermal management of the supercapacitors module, based on air-cooling is performed experimentally and numerically. The supercapacitors are charged and discharged with a current rate up to $70 \mathrm{~A}$ (the maximum authorized continuous current is $84 \mathrm{~A}[34])$ and with an inlet air velocity up to $0.6 \mathrm{~m} \mathrm{~s}^{-1}$. 


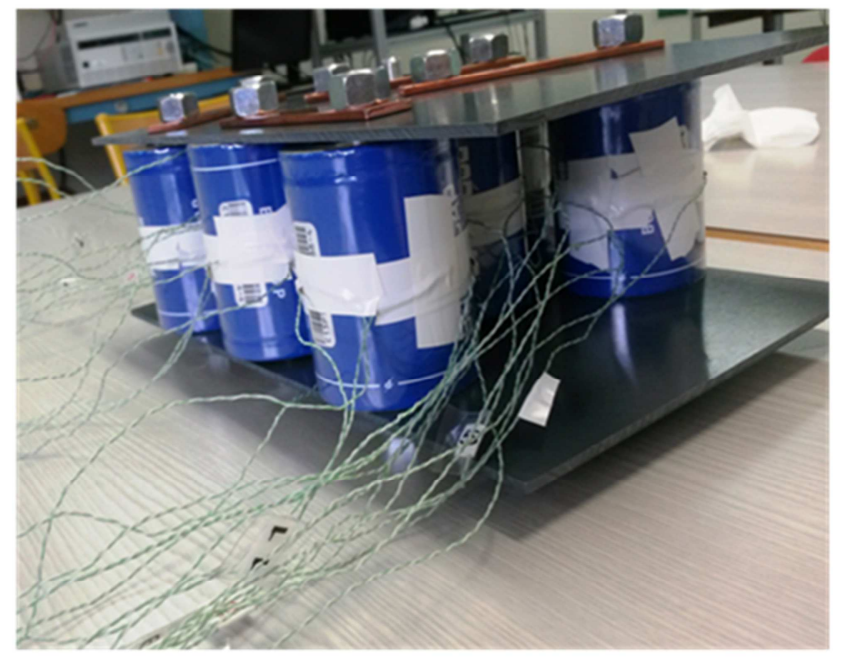

a. Supercapacitors module

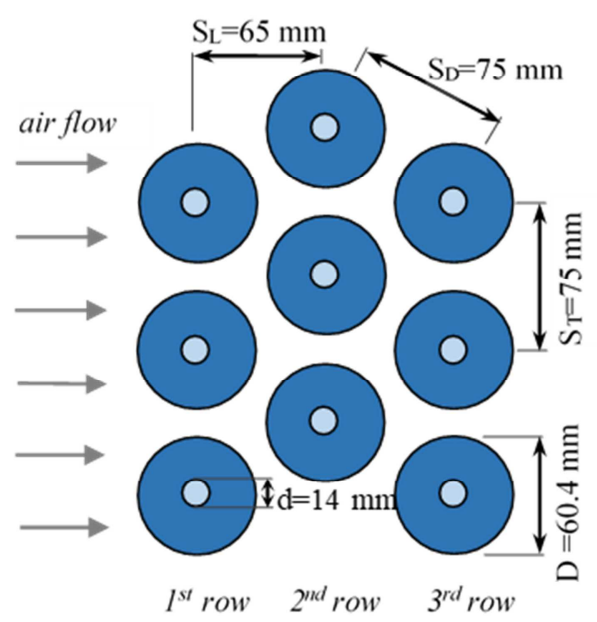

b. Configuration characteristics

Fig. 1 The supercapacitors arrangement

Several $\mathrm{K}$ - type thermocouples are placed on the surfaces of supercapacitors to provide information about the evolution of temperatures during tests.

The electrical circuit is composed of a DC power supply, an active load, and three mechanical relays. A voltmeter and a current clamp are inserted in the circuit to measure current and voltage during charge and discharge cycles.

\subsubsection{Experimental test section and uncertainties}

The experimental work is conducted in an open-loop experimental test section as shown in Fig. 2. The supercapacitors module is cooled using a fan with variable rotation speed. Cooling air is conducted through a circular cross section tube $(20 \mathrm{~cm}$ in diameter and $200 \mathrm{~cm}$ in length), a divergent tube with square cross section area $(50 \mathrm{~cm} \times 50 \mathrm{~cm})$ and a square section tube where the module is placed. An anemometer is placed in the circular section tube and is connected to NI data acquisition system to measure the linear velocity of cooling air. A honeycomb straightener is inserted at the outlet of the divergent in order to reduce the air turbulence at the entry of test area. 


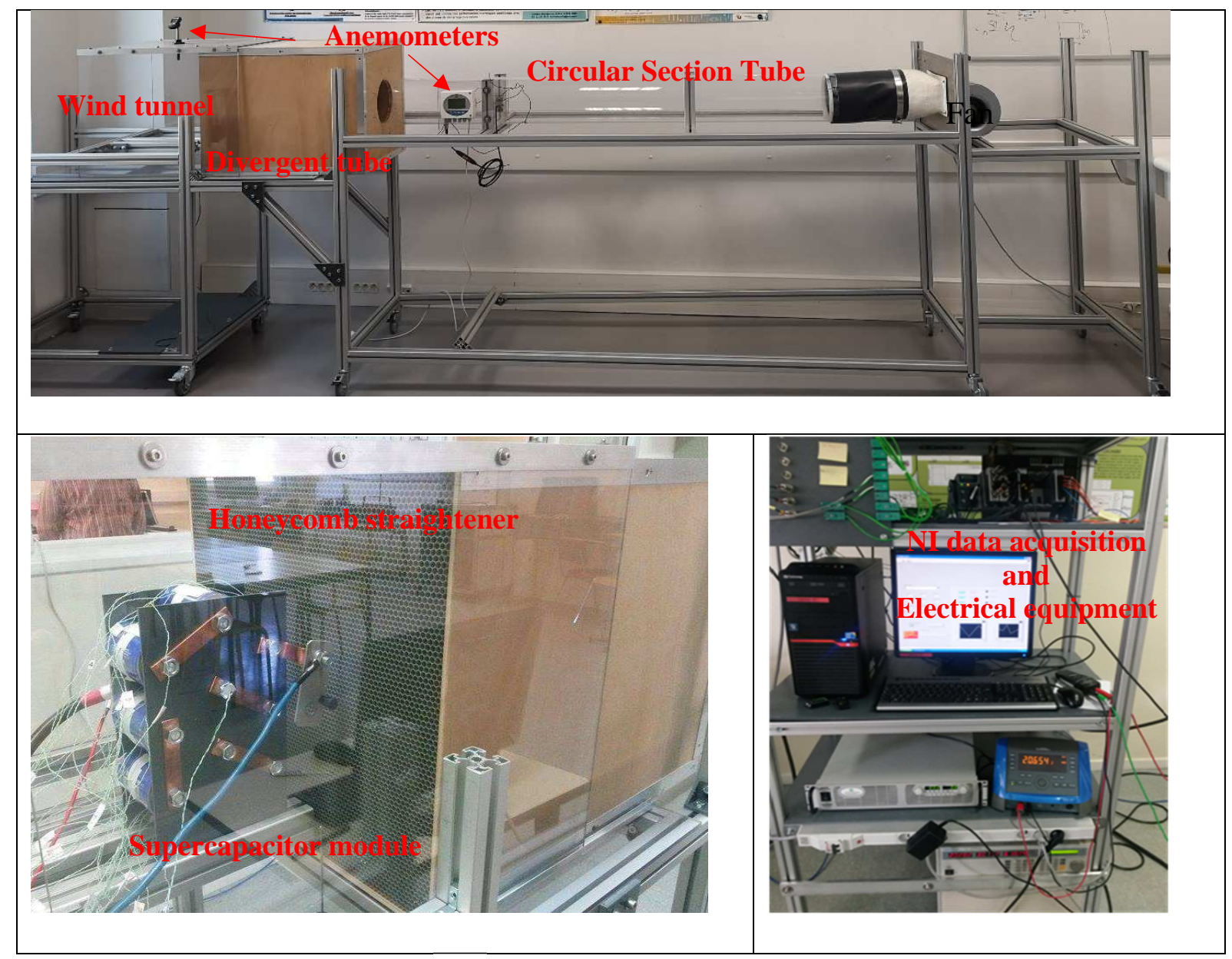

Fig. 2 The experimental airflow setup

The evolution of temperature is recorded for different airflow velocities and charging/discharging current loads. The operating temperature range of K-thermocouples is $-75{ }^{\circ} \mathrm{C}$ to $+250{ }^{\circ} \mathrm{C}$. All measuring devices are calibrated in our measurement range: thermocouples, anemometer, voltmeter, current clamp. Table 2 shows the uncertainties of different parameters.

Table 2 Uncertainties on the measured values

\begin{tabular}{ll}
\hline Parameters & Uncertainty \\
\hline Temperature $\left({ }^{\circ} \mathrm{C}\right)$ & \pm 0.25 \\
\hline Air velocity $\left(\mathrm{m} \mathrm{s}^{-1}\right)$ & \pm 0.03 \\
\hline Current rate $(\mathrm{A})$ & $\pm 2.5 \%$ \\
\hline Voltage $(\mathrm{V})$ & $\pm 1.8 \%$ \\
\hline Location and distances $(\mathrm{m})$ & $\pm 2 \%$ \\
\hline
\end{tabular}




\subsection{Experimental protocol}

Supercapacitors are charged and discharged between their nominal voltage (2.7 V) and half this voltage $(1.35 \mathrm{~V})$ because in this case they can store $75 \%$ of their maximal energy without causing electronic dysfunction. The module is charged and discharged with a voltage between $12 \mathrm{~V}$ and $24 \mathrm{~V}$. During charge, current flows from the power supply to the supercapacitors until the module reaches $24 \mathrm{~V}$, then it is discharged using the active load until the voltage reaches $12 \mathrm{~V}$. The duration of a charging/discharging cycle depends on capacitance $(\mathrm{C}=1500$ F), supercapacitor voltage variation $(\Delta \mathrm{U}=1.35 \mathrm{~V})$ and current rate (eq. 1). The tests are stopped when the steady state is reached.

$$
t_{c y c l e}=\frac{C \times \Delta U}{I}
$$

In natural convection experimental tests, the fan is turned off. The supercapacitiors undergo at least 70 charge/discharge cycles at current rates between $20 \mathrm{~A}$ and $70 \mathrm{~A}$. In forced convection experiments, the airflow velocity in the wind tunnel varies between $0.36 \mathrm{~m} \mathrm{~s}^{-1}$ and $0.59 \mathrm{~m} \mathrm{~s}^{-1}$. The supercapacitors undergo at least 35 charge/discharge cycles at 70 A current rate. Each test is repeated at least two times.

The inlet temperature corresponds to the temperature of the room where the experiment takes place and is not controlled. It varies during the tests between 20 and $24{ }^{\circ} \mathrm{C}$.

All measured parameters are logged using NI data acquisition system. LabVIEW software is used to process logged data and to command charging/discharging process of supercapacitors. The acquisition frequency is 1 Hertz.

\section{Mathematical modelling}

The study deals with a supercapacitor stack in staggered pattern of three rows in the airflow direction. For safety reasons, the experiments are performed up to $83 \%$ of maximum 
authorized continuous current rate. The objective of the models proposed below is to predict the thermal behaviour of the module at high current rates close to the limits of use.

\subsection{Mathematical modelling for natural convection}

The model proposed below uses the results of tests carried out at safe conditions of use. The aim of the approach is to predict the thermal behaviour at high current rates.

The simple empirical correlations for the average Nusselt number $(\mathrm{Nu})$ in natural convection are given by [22]:

$$
N u=\frac{\bar{h}_{c} \times L_{c}}{\lambda}=C_{1} R a_{L}^{m}
$$

Where $\bar{h}_{c}$ is the average heat transfer coefficient, $L_{c}$ is the characteristic length (for one horizontal cylinder $L_{c}=D$, but for a bank of cylinders it is difficult to determine), $\lambda$ is the thermal conductivity and $\mathrm{Ra}$ is the Rayleigh number.

$$
R a=\frac{g \times \beta \times\left(T_{S}-T_{0}\right) \times L_{c}{ }^{3}}{v \times \alpha}
$$

The constant $C_{1}$ depends on the geometry and it is generally less than 1 . The constant $m$ depends on the regime flow, which is characterized by the range of the Rayleigh number. It is usually 0.25 for laminar flow and 0.33 for turbulent flow [22]. Equations (2) and (3) show that:

$$
\bar{h}_{c} \propto\left(T_{s}-T_{0}\right)^{m}
$$

On the other hand, when the average Nusselt number and thus the average convection coefficient is known, the rate of heat transfer by natural convection from a solid surface at temperature $\mathrm{T}_{\mathrm{s}}$ to the surrounding fluid is expressed by Newton's law of cooling as

$$
\dot{Q}_{\text {module }}=\bar{h}_{c} \times A_{s} \times\left(T_{s}-T_{0}\right)
$$

Moreover, for the supercapacitor module, the heat transfer can be calculated as:

$$
\dot{Q}_{\text {module }}=n \times E S R \times I^{2}
$$


Where $n$ is the number of supercapacitors, ESR is the Maximum Equivalent Resistance, and I is the current rate.

From equations (4)-(6), we can deduce that the values of $\Delta \mathrm{T}_{\max }$ (maximum relative surface temperature) can be interpolated as:

$$
\Delta T_{\max }=C_{2} I^{2 / m+1}
$$

These predicted curves help to estimate the maximal relative surface temperature at current rates close to the limits of use.

\subsection{Mathematical modelling for forced convection}

\subsubsection{Field computation}

The calculations are performed for a domain that reproduced the geometrical and experimental flow conditions. A 3D computational domain is created and different symmetrical planes are used to simplify the computational domain and reduce computational time. For computational reasons [35,36], additional adiabatic zones extend the domain upstream and downstream of the heat transfer zone.

On the other hand, in each supercapacitor, two different zones are considered. Near the axis, up to $d$ diameter (see Fig. 1b), it is a region which does not stock energy. There is a homogeneous material with a constant $3 \mathrm{D}$ thermal conductivity $\left(\lambda_{\mathrm{b}}=0.19 \mathrm{~W} \mathrm{~m}^{-1} \mathrm{~K}^{-1}\right)$. Beyond this central zone to the outer edge, it is the active zone for electrical energy storage. There is a multilayer material made of layers of aluminium foils covered on both sides with carbon particles and a separator foil. That way, the aluminium collector foil is not interrupted by insulating material along the supercapacitor axis and along the azimuth, and the thermal conductivity is much greater than in the radial direction [28,32,37]. Fig. 3 presents an illustration of the repeating element of the multilayer material of the active zone depicted in a recent study [37]. 


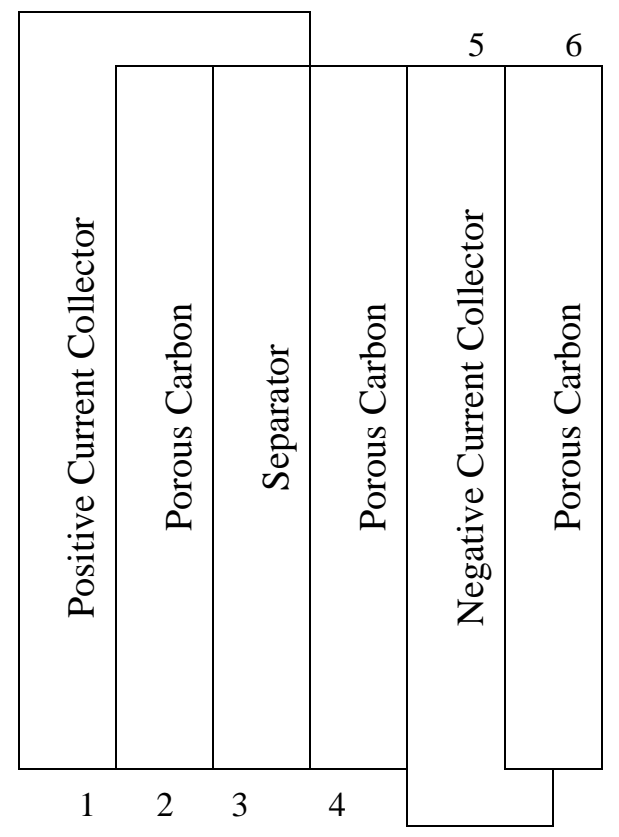

Fig. 3 Multilayer material of the active zone of the supercapacitor [37]

The thermal conductivities of the materials are taken from literature [37-40] and are shown in Table 3. The equivalent thermal conductivity of the active zone is implemented in the model as:

$\lambda_{e q r}=\frac{\sum_{i=1}^{6} e_{i}}{\sum_{i=1}^{6} \frac{e_{i}}{\lambda_{i}}} \quad($ Serial thermal resistances on radial coordinate direction $)$

$\lambda_{e q z, \theta}=\frac{\sum_{i=1}^{6} \lambda_{i} \times e_{i}}{\sum_{i=1}^{6} e_{i}}$ (Parallel thermal resistances on axial and angular coordinate direction)(9)

Table 3 Properties of the multilayer material (storage active zone)

\begin{tabular}{|c|c|c|c|}
\hline $\begin{array}{c}\text { No } \\
\text { layer }\end{array}$ & Material & $\begin{array}{c}\text { Thickness } \\
e[\mu \mathrm{m}] \\
{[32]}\end{array}$ & $\begin{array}{c}\text { Thermal } \\
\text { conductivity } \lambda \\
{\left[\mathrm{W} \mathrm{m}^{-1}{ }^{\circ} \mathrm{C}^{-1}\right]}\end{array}$ \\
\hline 1,5 & $\begin{array}{c}\text { Aluminium } \\
\text { current collector }\end{array}$ & 25 & $237[39]$ \\
\hline $2,4,6$ & $\begin{array}{c}\text { Carbon electrode } \\
\text { (wet) }\end{array}$ & 120 & $0.44[38]$ \\
\hline 3 & Separator & 40 & $0.22[37],[40]$ \\
\hline$\Rightarrow$ & $\begin{array}{c}\text { Repeating } \\
\text { element / All } \\
\text { active zone }\end{array}$ & 450 & $\begin{array}{c}\lambda_{\mathrm{r}}=0.45 \\
\lambda_{\mathrm{z}}=\lambda_{\theta}=22.89\end{array}$ \\
\hline
\end{tabular}


The specific heat capacity $\left(c_{p}\right)$ and the density $(\rho)$ of the active zone are respectively $1058 \mathrm{~J} \mathrm{~kg}^{-1}{ }^{\circ} \mathrm{C}^{-1}$ and $1200 \mathrm{~kg} \mathrm{~m}^{-3}[32]$.

The thickness of the sheath wall is $3 \mathrm{~mm}$. Plexiglas material is considered, except the zones near the axis of supercapacitors. So, up to $d$ diameters (see Fig 1), a material with thermal proprieties of steel is considered, in order to take into account the fastener that acts like a thermal bridge.

\section{Governing equations}

The three-dimensional flow is assumed to be steady. Air properties are assumed to be constant and evaluated at the inlet temperature of air flow. The radiation heat transfer is neglected. The heat transfer is steady or transient (for steady heat transfer, the transient term $\frac{\partial T}{\partial t}=0$ )

With these assumptions, the thermo-hydrodynamic evolution of the air is modelled by the following equations:

Conservation of mass:

$$
\nabla \cdot v=0
$$

Conservation of momentum:

$$
(v \cdot \nabla) v=-\frac{\nabla p}{\rho}+v \nabla^{2} v
$$

Conservation of energy:

$$
(v . \nabla) T+\frac{\partial T}{\partial t}=\alpha \nabla^{2} T
$$

A part of the electrical energy crossing the active zone is transformed into Joule heating. The heat dissipated from a supercapacitor is calculated with the following expression and presented as a function of current rate in Fig. 4:

$$
\dot{Q}=E S R \times I^{2}, \text { where } I=\frac{\int_{t_{i}}^{t_{f}}|I(t)| d t}{t_{f}-t_{i}}
$$




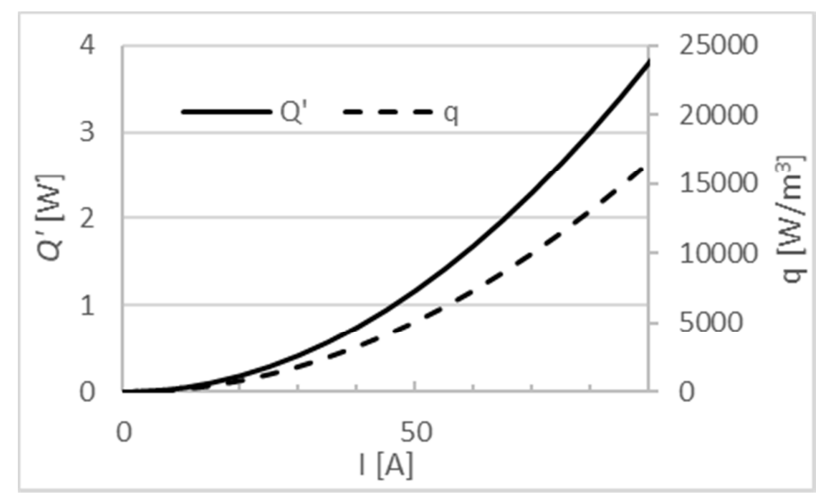

Fig. 4 Heat dissipated for different current rates

Spatial thermal conductivity variation in the multilayer cell is taken into account.

With these assumptions, for the solid, conservation energy is expressed as:

In the multilayer domain (active zone) :

$$
\begin{aligned}
& \qquad\left(\lambda . \nabla^{2}\right) T+q=\rho C_{P} \frac{\partial T}{\partial t} \\
& \text { where } q=\frac{\dot{Q}}{L \times \frac{\pi}{4} \times\left(D^{2}-d^{2}\right)}
\end{aligned}
$$

In the central domain and in the sheath wall:

$$
\lambda \nabla^{2} T=\frac{\partial T}{\partial t}
$$

\subsubsection{Boundary conditions and initial conditions}

Mathematically, the boundary conditions are defined as follows:

- At the inlet of the extended domain, uniform velocities and temperature profiles are considered.

- At the outlet of the extended domain, pressure is equal to the atmospheric pressure and the axial variation of temperature is equal to zero.

- The no-slip condition and zero normal pressure gradient are the boundary conditions used on all solid-fluid interfaces.

- At the sheath wall external surface, local convection heat transfer is considered: $\varphi_{i}=\bar{h}_{c} \times\left(T_{i}-T_{0}\right)$. The relation $N u=\frac{\bar{h}_{c} \times L_{c}}{\lambda}=0.664 \operatorname{Re}^{0.5} \times \operatorname{Pr}^{1 / 3}$ [22] gives the 
average heat transfer coefficient $\left(\bar{h}_{c}\right)$ for the entire plate. Note that the value of the characteristic length $\left(L_{c}\right)$ is the length of the experimental sheath wall in the flow direction, the Re number is expressed with $v_{0}$, and the term $T_{i}$ represents the local temperature of the sheath.

- At the interfaces between solid-fluid or solid-solid parts, the uniformity of heat flux and temperature is applied on the surfaces normal direction: $\lambda_{i}\left(\partial \mathrm{T}_{\mathrm{i}}\right) / \partial \mathrm{n}=\lambda_{\mathrm{j}}\left(\partial \mathrm{T}_{\mathrm{j}}\right) / \partial \mathrm{n}$ and $T_{i}=T_{j}$, where $i$ and $j$ are the subscripts of the parts separated by the interface.

The inlet air temperature is the initial temperature condition over the domain. The steady state run uses an automatic initial guess for the velocity field. Transient run starts with results from a converged steady-state solution without internal heat source.

\subsubsection{Numerical solution}

In this study, commercial computational fluid dynamics package, Ansys Fluent 14.6, is used [41]. The governing differential equations of fluid flow and heat transfer are solved using the numerical method based on "finite volume approach". The pressure based solver option is selected for the present computation. The coupling between velocity and pressure is solved by selecting SIMPLE (Semi-Implicit Method for Pressure Linked equations) algorithm. For transient cases simulation time step is set to $1 \mathrm{~s}$ and the number of iterations per time step is to 100. The absolute convergence criterion is set so that the residuals of the energy equation and flow equations are $10^{-6}$.

\section{Forced convection model validation}

There are no experimental results regarding the case of the heat transfer and flow for a supercapacitor module using the arrangement considered in the present study. Therefore, in order to validate the computer model, the numerical results are compared to available data obtained previously $[22,42]$ for a tube bank with the same geometry as the present study. The uncertainty in the values of Nusselt number and friction factor obtained from these relations is 
$\pm 15 \%$. The velocities, and consequently the Reynolds number, correspond to the values considered for the experimental tests. The aim is to ensure that the numerical model appropriately considers the heat transfer and the flow between the geometry of the module and the air.

Fig. 5 and Table 4 show the validation of the turbulence model. The Shear-Stress Transport (SST) k- $\omega$ model is used for turbulent viscosity, but the agreement appears quite acceptable (less than 15\%) also for one equation Spalart -Allmaras (SA) turbulent viscosity model. The model SST k- $\omega$ model [43] is a combination of a k- $\omega$ model (in the inner boundary layer) and a k- $\varepsilon$ model (in the outer region of the boundary layer as well as outside it). The k- $\omega$ model is well suited for prediction near the wall, while the $\mathrm{k}-\varepsilon$ model is used for the remaining area near the boundary region.
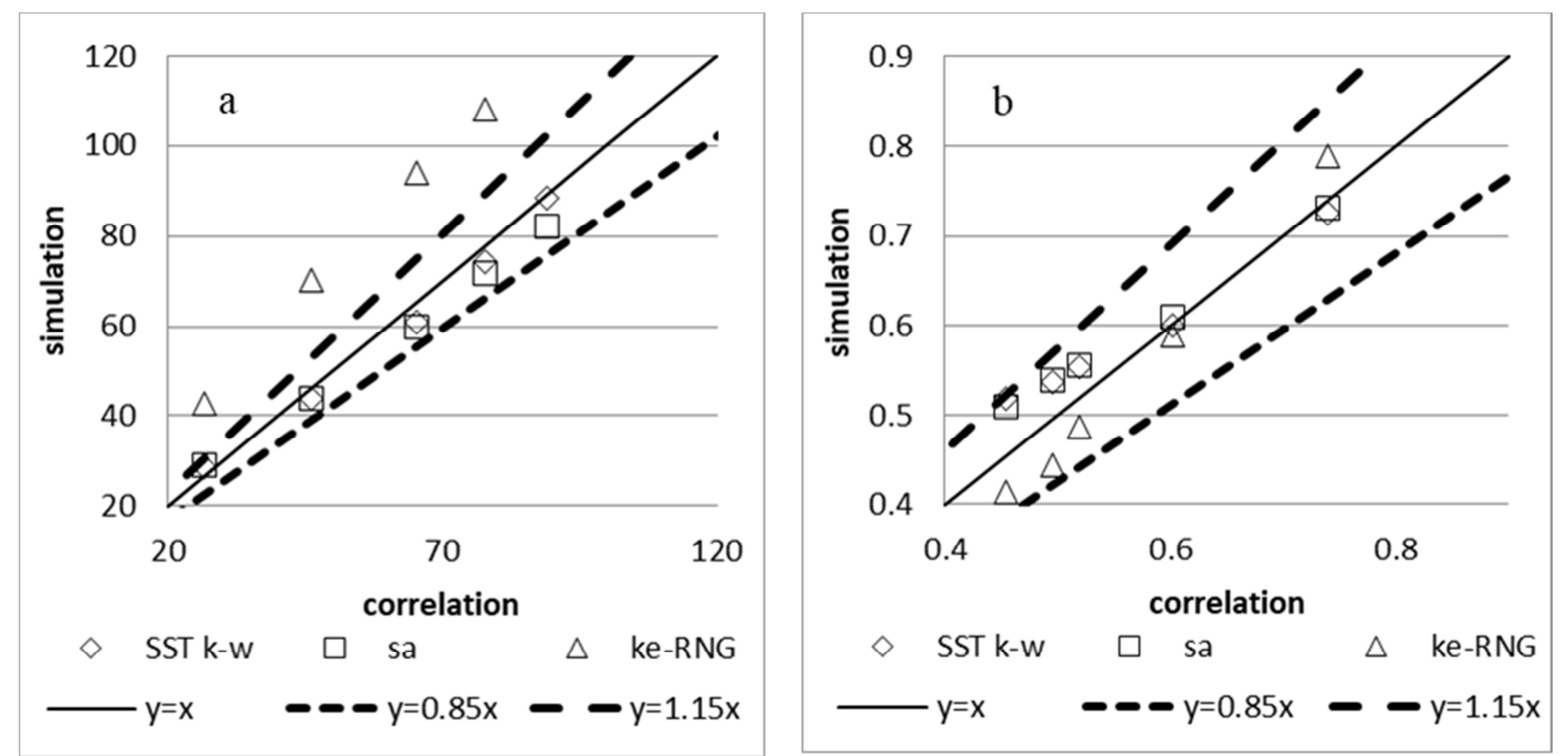

Fig. 5 Computer model validations:

a) Comparison of Nusselt number between the simulated results and calculated results using empirical correlation by [42], presented more recently by [22]

b) Comparison of Friction factor between the simulated results and plotted in charts experimental results by [42], presented more recently by [22]

The present numerical predictions are very close to the corresponding experimental correlation values. The deviation is constantly less than $15 \%$. In the light of validation tests above, one can conclude about the appropriateness of the mathematical model as well as the reliability of the numerical method adopted. 
Table 4 Computer model validation: comparison of Nusselt number / Friction factor number versus Reynolds number between the simulated and theoretical [22] results

\begin{tabular}{|c|c|c|c|c|c|c|c|c|c|c|}
\hline $\begin{array}{l}\mathrm{v}_{0} \\
{[\mathrm{~m} / \mathrm{s}]}\end{array}$ & $\begin{array}{l}v_{\max } \\
{[\mathrm{m} / \mathrm{s}]}\end{array}$ & $\mathrm{Re}_{\max }$ & $\mathrm{Nu}_{\text {theoretical }}$ & $f_{\text {theoretical }}$ & $\mathrm{Nu}_{\text {SST }} \mathrm{k}-\omega$ & $f_{\text {SST k- } \omega}$ & $\mathrm{Nu}_{\mathrm{SA}}$ & $f_{\mathrm{SA}}$ & $\mathrm{Nu}_{\mathrm{k} \varepsilon-\mathrm{RNG}}$ & $f_{\mathrm{k} \varepsilon-\mathrm{RNG}}$ \\
\hline 0.1 & 0.5 & 67 & $1-$ & 0.74 & 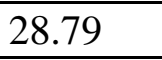 & 0.725 & 28.96 & 0.731 & 42.63 & 0.789 \\
\hline 0.25 & 1.25 & 8 & 4 & 0.602 & 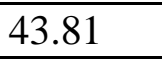 & 0.6 & 43.97 & 0.61 & 70.14 & 0.59 \\
\hline 0.45 & 2.25 & 9303 & 65.46 & 0.52 & 1.12 & 0.553 & 59.85 & 0.556 & 94.16 & 0.486 \\
\hline 0.6 & 3 & 12404 & 77.8 & 0.495 & 74.43 & 0.537 & \begin{tabular}{|l|}
71.78 \\
\end{tabular} & 0.538 & 108.19 & 0.443 \\
\hline 0.75 & 3.75 & 15505 & 88.94 & 0.455 & 88.5 & 0.518 & 82.03 & 0.509 & 122.18 & 0.414 \\
\hline
\end{tabular}

A grid independence test is carried out with $0.4,0.66$ and 1.09 million elements. The deviation of the Nusselt number and friction factor compared to the corresponding experimental correlation (the same method as for the choice of turbulence model) is used. For 0.4 million elements the deviation is greater than $15 \%$. For 0.66 and 1.09 million elements, the simulation results do not change a lot with the number of mesh. We also chose the coarse mesh for computational reasons. Thus the grid for the computations is composed of 0.66 million computational cells. The results presented in Fig. 5 and Table 4 are obtained with this grid. Furthermore, a final grid that would try to meet all the necessary requirements for a good mesh is achieved. For example, the discretization grid is finer near the solid-fluid interfaces, where gradients of velocity and temperature are important, and $y+$ is less than 4 and mean value is 1.3 .

\section{Results}

In natural convection experimental tests, the fan is turned off. The supercapactors undergo charge/discharge cycles at current rates between $20 \mathrm{~A}$ and $70 \mathrm{~A}$. Forced convection is the chosen solution to enhance heat transfer. In forced convection experiments, the airflow velocity in the wind tunnel varies up to $0.59 \mathrm{~m} \mathrm{~s}^{-1}$ and the current rate is $70 \mathrm{~A}$. The airflow velocities are low because the benefits of enhancing heat transfer in a supercapacitor stack should be weighed against the cost of additional power requirements. Thus, fan power and especially the ratio between fan power and maximal temperatures are also very important.

Fig. 6 presents charge/discharge cycle at 30 A continuous current rate. 


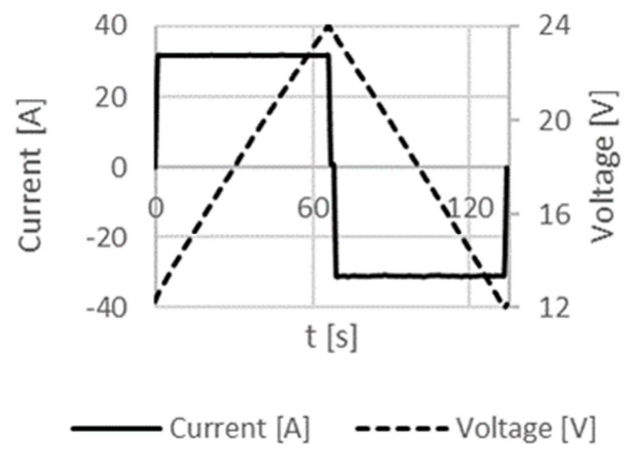

Fig. 6 Charge / Discharge cycles of the supercapacitors module at 30A

To compare the results of different tests, it is more appropriate to use the relative temperatures rather than the absolute temperatures since the ambient temperature varies from one test to another and sometimes even during the same test.

The graph of Fig. 7 shows the evolution of maximum relative temperature (difference between maximum temperature of the supercapacitors module and ambient air temperature) as a function of time for five charging / discharging currents in natural convection. In natural convection the higher the current, the higher the maximum temperature. After 1 hour and 45 minutes the temperature difference reaches $4{ }^{\circ} \mathrm{C}$ for $25 \mathrm{~A}$ and $20{ }^{\circ} \mathrm{C}$ for $70 \mathrm{~A}$. Natural and forced convection are compared for 70 A current rate to. For $0.36 \mathrm{~m} \mathrm{~s}^{-1}$ airflow velocity, the steady state is reached faster and the maximum relative temperature decreases from $22{ }^{\circ} \mathrm{C}$, in natural convection, to $6.8^{\circ} \mathrm{C}$.

The tests carried out in natural convection show that the supercapacitor located in the middle of the stack has the maximum surface temperature and the temperature distribution has a vertical symmetry. The graph of Fig. 8 presents the maximum (asymptotic) temperature variation as a function of the charging / discharging current rate when the fan is turned off.

That it is not a linear curve. This evolution is related to equation (7). The best achievement is obtained with $\mathrm{C}_{2}=0.34$ for laminar convection $(m=0.25)$ and with $\mathrm{C}_{2}=0.25$ for turbulent convection $(m=0.33)$. 
These projection curves help us estimate the maximum relative surface temperature at $84 \mathrm{~A}$ (the maximum current rate) between 26.6 and $30{ }^{\circ} \mathrm{C}$. These results show that overheating can occur for high current rates and air temperature higher than $30{ }^{\circ} \mathrm{C}$, so a ventilation cooling system can be useful.

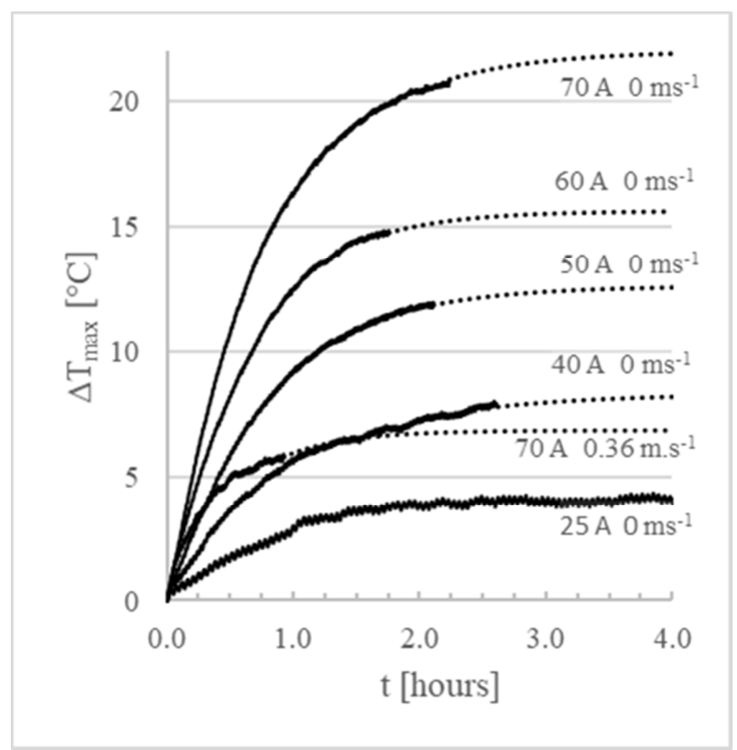

Fig. 7 Evolution of maximal relative temperature in transient and steady state temperature process in natural and forced convection

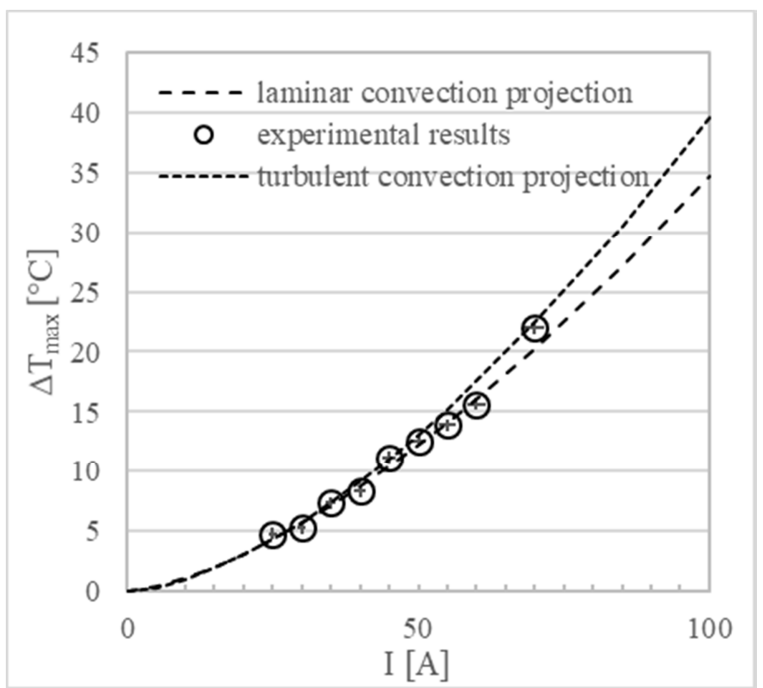

Fig. 8 Evolution of temperature difference between maximal surface temperature of supercapacitor stack and inlet air flow for steady natural convection

The results presented hereafter are obtained with the fan turned on (forced convection) by using a current rate of $70 \mathrm{~A}$ for charge/discharge. This value is chosen because it enables us in 
the experimental tests to obtain significant overheating while keeping the operating mode well below the maximum recommended manufacturer's current rating of $84 \mathrm{~A}$.

In Fig. 9 and Fig. 10 the numerical results are presented and compared with the experimental results for steady state forced convection regime. At the inlet, the velocity is $0.36 \mathrm{~m} \mathrm{~s}^{-1}$ $(\operatorname{Re}=4365)$ and the temperature is $21.9^{\circ} \mathrm{C}$. Two significant sections are chosen:

a) the perpendicular plan which divides each supercapacitor into two equal cylindrical volumes. It is chosen because the most important overheating is recorded there

b) the plan which includes the axis of $2^{\text {nd }}$ supercapacitor. It is chosen to show that in the axial direction the temperature of the supercapacitors varies much less than in the radial direction.

The numerical and experimental results match. The second row has the best cooling, despite its central position. The first row is the least well cooled, but its temperature is very close to that of the last row of supercapacitors. The lowest temperature of the second row compared to the first row is explained by the increase in turbulence during the passage of the air flow through the first row. As a result, the heat transfer increases in the second row. In the third row, the effects of the increase in turbulence and therefore of the local heat transfer coefficient on the temperature of the supercapacitors are less visible because the temperature of air increases during its passage through the first two rows. The third row is also less well cooled than the second because it is the last row of the module and an important downstream flow recirculation field decreases the local heat transfer. Likewise, the maximum surface temperature is located in the last row, downstream of the last supercapacitor.

The numerical results allow us to estimate the temperature distribution in the middle of supercapacitors. The maximum temperature of the module is located in the first row around the axis of the supercapacitor. For these operating parameters, it is approximately $32.3{ }^{\circ} \mathrm{C}, 3$ ${ }^{\circ} \mathrm{C}$ greater than the maximum surface (external) temperature and up to $10{ }^{\circ} \mathrm{C}$ higher than the air blowing temperature. It is important to note that the temperature contours of each 
supercapacitor are almost concentric around its axis and the axial temperature variations are not important.

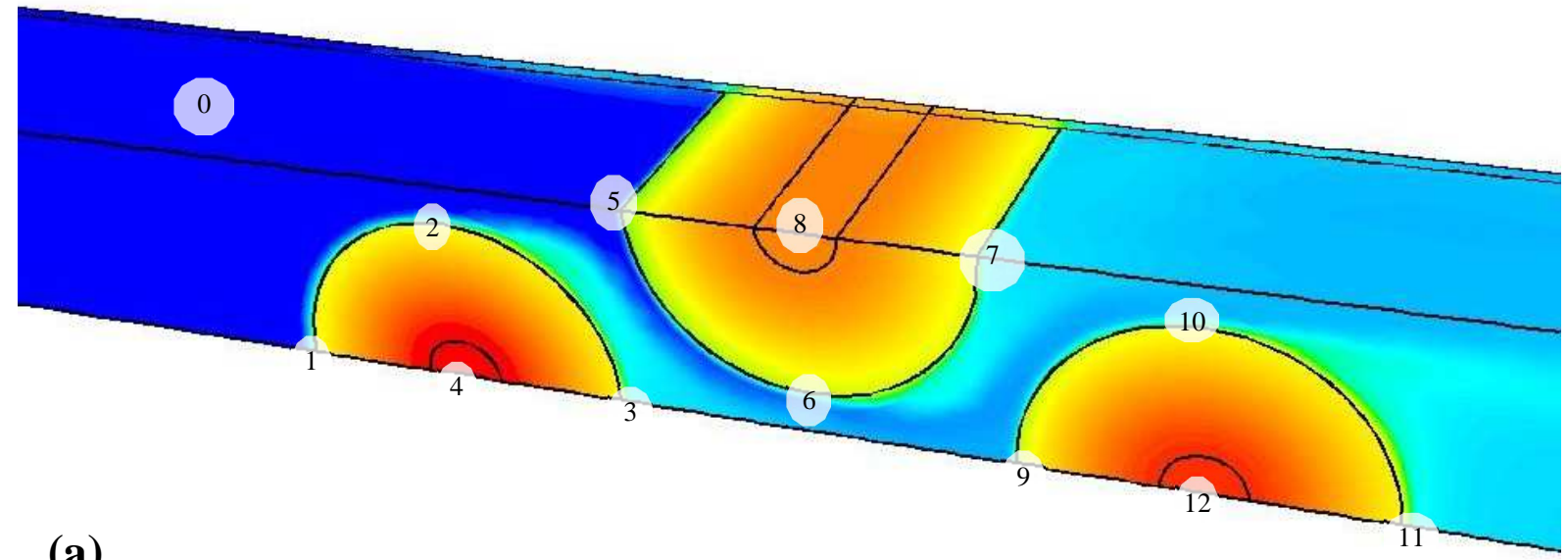

(a)
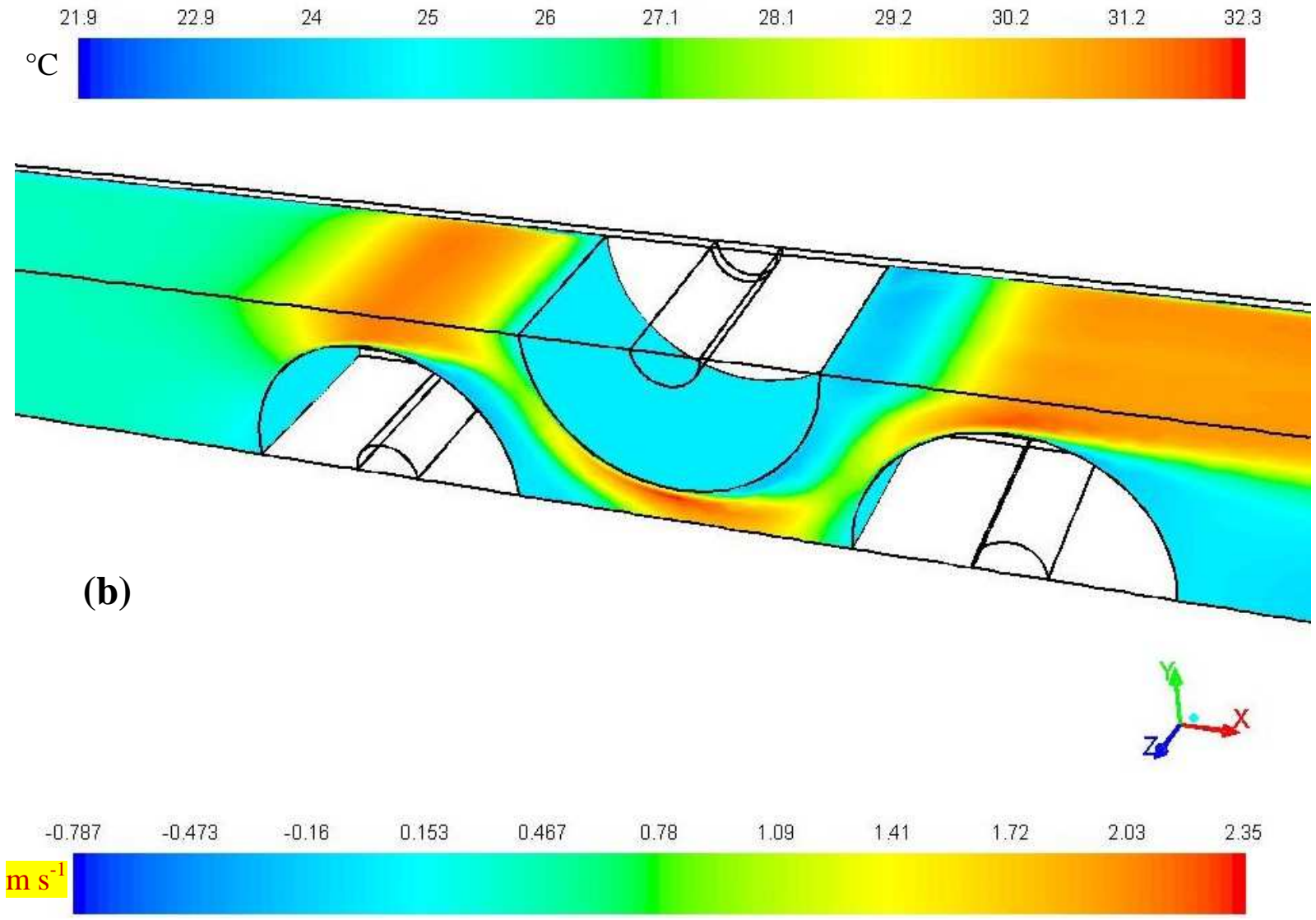

Fig. 9 Numerical simulation results: (a) Temperature contours, (b) x velocity contours 


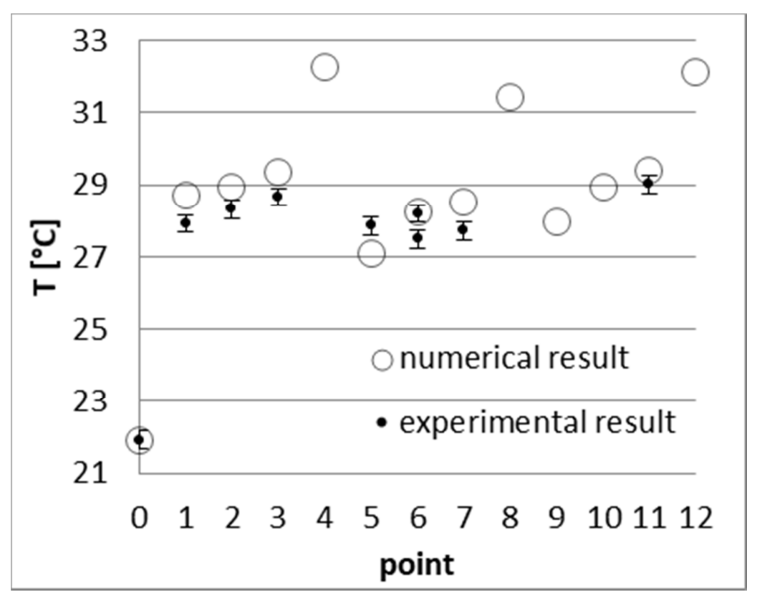

Fig. 10 Local surface temperatures

In Fig. 11, different cases are presented for forced convection steady state regime. To compare the results of different tests, it is more appropriate to use the relative temperatures rather than the absolute temperatures since the ambient temperature varies from one test to another and sometimes even during the same test. For the experimental results, temperature is obtained for $\mathrm{t}=4$ hours (Fig.7) and at that moment, the evolution is asymptotic. Numerical investigation is conducted for steady state regime. The numerical and experimental results match. The mean deviation between experimental and numerical relative temperatures is 19.8\%. Richardson number is always less than 0.03 and that confirms forced convection assumption in the numerical model. Up to $0.36 \mathrm{~m} \mathrm{~s}^{-1}$ inlet airflow, the maximum external temperature is located in the last row (point 11 on Fig. 9a), while for greater velocity it is located in the first row (point 3 on Figure 9a). Numerical results estimate the maximal inside temperature. For $0.2 \mathrm{~m} \mathrm{~s}^{-1}$ inlet airflow, the maximum inside temperature is located in the last row (point 12 in Fig. 9a), but for the simulations with greater velocity it is located in the first row (position 4 in Fig. 9a). The difference between maximum internal and maximum surface temperature is between 2.5 and $3{ }^{\circ} \mathrm{C}$.

In Fig. 12, transient numerical and experimental results are compared. The current rate is 70 A. At the entrance, the average speed is $0.36 \mathrm{~m} \mathrm{~s}^{-1}$. The module is at room temperature before 
starting the successive charging / discharging cycles. The surface supercapacitor temperature is recorded at position 11 of Fig. 9a.

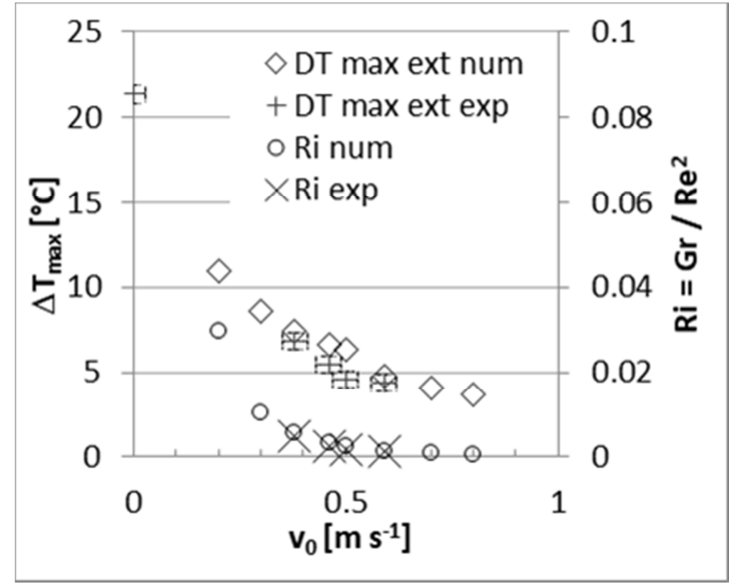

Fig. 11 Evolution of maximum local experimental temperature and maximum local numerical temperature for several inlet airflow velocities

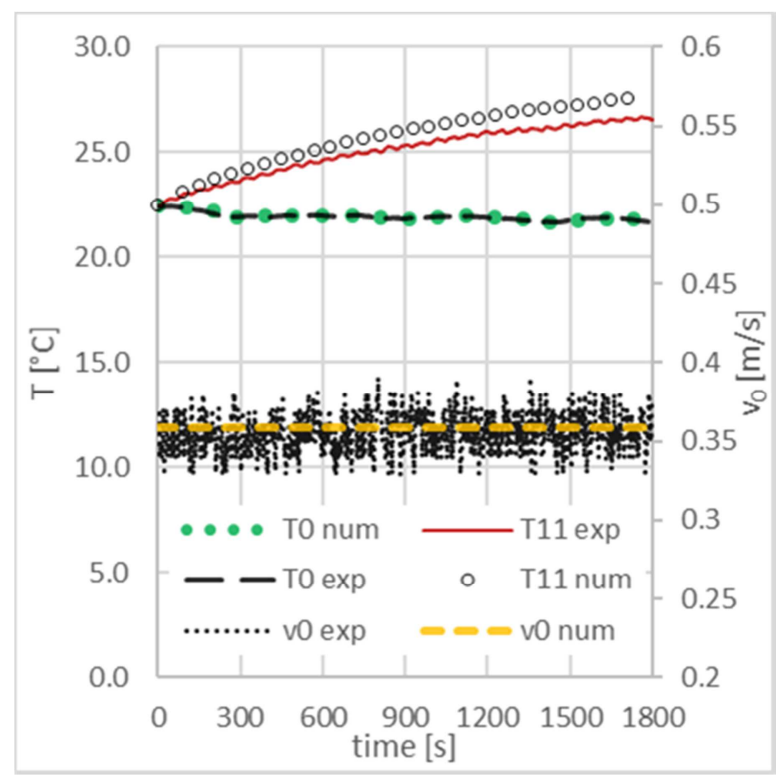

Fig. 12 Evolution of transient temperatures

The numerical and experimental results are in good agreement. The deviation between experimental and numerical relative temperatures is constantly less than $20 \%$ throughout the period considered, with a mean value of $17.5 \%$. After half an hour of operation, a difference of approximately $1{ }^{\circ} \mathrm{C}$ is noted.

Thereafter, we use the numerical simulations to study the temperatures evolution for maximal current rate $\left(\mathrm{I}_{\max }=84\right.$ A) and $40{ }^{\circ} \mathrm{C}$ inlet air velocity. This limit situation is difficult to achieve experimentally for safety reasons. 
In Fig. 13 the maximal temperatures are presented for several inlet air flow velocities. The results obtained with a steady state regime show that the overheating is possible with a velocity less than $0.15 \mathrm{~m} \mathrm{~s}^{-1}$. Up to $0.4 \mathrm{~m} \mathrm{~s}^{-1}$ the overheating is at less $10{ }^{\circ} \mathrm{C}$. The results obtained after four minutes of operation (10 cycles charge-discharge) show that the temperature of supercapacitors is less that $42.5^{\circ} \mathrm{C}$ and is not influenced by the air velocity.

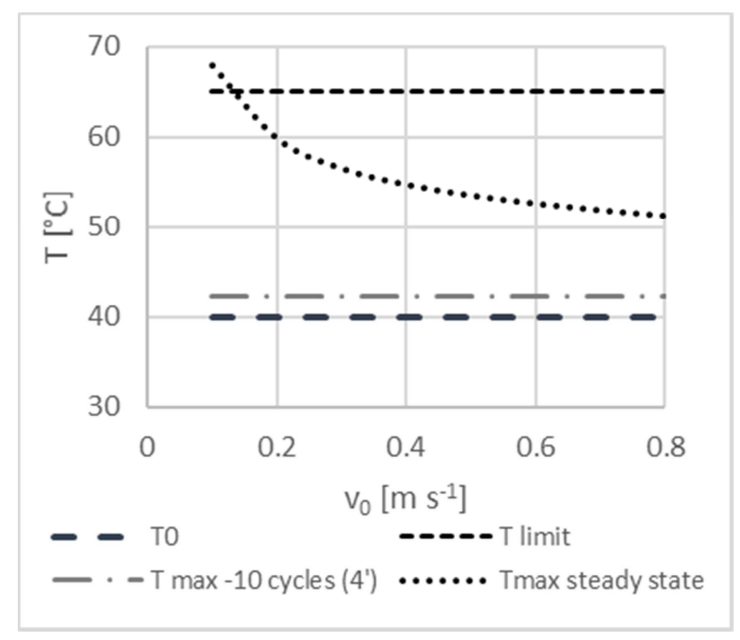

Fig. 13 Evolution of maximal temperatures with $\mathrm{I}_{\max }(84 \mathrm{~A})$

Fig. 14 presents the contours of temperatures for $0.1 \mathrm{~m} \mathrm{~s}^{-1}$ inlet air velocity and four minutes of operation. As with permanent regime (Fig. 9a), the temperature contours of each supercapacitor are almost concentric around its axis and the axial temperature variations are not important. However, for this transient regime we observe that the maximum temperatures are located inside the active zone and not near the axis as for steady state regime.

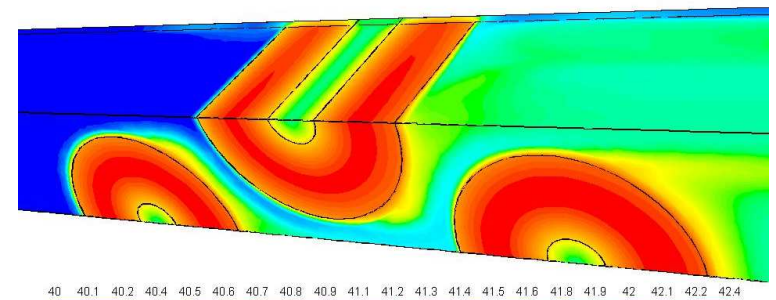

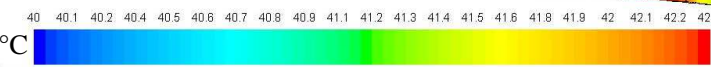

Fig. 14 Temperature contours after four minutes of operation with $\mathrm{I}=\mathrm{I}_{\max }=84 \mathrm{~A}$, $\mathrm{v}_{0}=0.1 \mathrm{~m} \mathrm{~s}^{-1}$ and $\mathrm{T}_{0}=40{ }^{\circ} \mathrm{C}$ 


\section{Conclusion and outlook}

Thermal management of a module of nine supercapacitors is studied experimentally and numerically for a three-row staggered arrangement. The supercapacitors are charged and discharged with a current rate up to $70 \mathrm{~A}$ and with an inlet air velocity up to $0.8 \mathrm{~m} \mathrm{~s}^{-1}$. In a first step, an experimental natural convection study is conducted. The second row has the worst cooling and the temperature distribution presents a vertical plane of symmetry. The temperature difference between inlet airflow and maximal external temperature reaches $4{ }^{\circ} \mathrm{C}$ for $25 \mathrm{~A}$ and $20{ }^{\circ} \mathrm{C}$ for $70 \mathrm{~A}$ after 1 hour and 45 minutes. The evolution of the relative maximal external temperature as a function of the intensity of the current show that the overheating is possible for high current rates.

The second part of the study focuses on forced convection air-cooling for $70 \mathrm{~A}$ current rate of charge-discharge cycles. The numerical and experimental steady state and transient results match. The deviation between experimental and numerical relative temperatures remains lower than $20 \%$. For the considered cases, the numerical model predicts higher temperatures than those measured experimentally.

The second row has the best cooling despite its central position. In contrast, the warmer supercapacitor is not always on the same row. Up to $0.36 \mathrm{~m} \mathrm{~s}^{-1}$ inlet airflow, the maximum external temperature is located in the last row, while for greater velocity it is located in the first row. However, for the same inlet air velocity the values are very close.

The numerical simulation allows the estimation of the internal temperature too. In all supercapacitors, the temperature distribution is concentric with the maximum in the axis, and axial temperature variations are not important, compared to variation in the radial direction. The difference between maximal internal and maximal external module temperature is between 2.5 and $3{ }^{\circ} \mathrm{C}$. 
The third part of the study focuses on numerical simulations to study the temperatures evolution for maximal current rate $\left(\mathrm{I}_{\max }=84 \mathrm{~A}\right)$ and $40{ }^{\circ} \mathrm{C}$ inlet air velocity. Overheating is possible at steady state regime with a velocity less than $0.15 \mathrm{~m} \mathrm{~s}^{-1}$. On the other hand, after four minutes of operation the temperature of supercapacitors is less than $42.5^{\circ} \mathrm{C}$ and is not influenced by air velocity. For this transient regime, the maximum temperatures are located inside the active zone.

Thereafter, it can be interesting to extend the numerical simulations to study the overheating limit situations difficult to achieve experimentally for safety reasons.

\section{References}

[1] R. Kötz, M. Carlen, Principles and applications of electrochemical capacitors, Electrochim. Acta. 45 (2000) 2483-2498. doi:10.1016/S0013-4686(00)00354-6.

[2] G. Xiong, A. Kundu, T.S. Fisher, Thermal effects in supercapacitors, in: 2015: pp. 1-13. doi:10.1007/978-3-319-20242-6_1.

[3] Y. Wang, F. Ronilaya, X. Chen, A.P. Roskilly, Modelling and simulation of a distributed power generation system with energy storage to meet dynamic household electricity demand, Appl. Therm. Eng. 50 (2013) 523-535. doi:10.1016/J.APPLTHERMALENG.2012.08.014.

[4] M.Y. Ayad, M. Becherif, A. Henni, Vehicle hybridization with fuel cell, supercapacitors and batteries by sliding mode control, Renew. Energy. $36 \quad$ (2011) 2627-2634. doi:10.1016/J.RENENE.2010.06.012.

[5] T. Ma, H. Yang, L. Lu, Development of hybrid battery-supercapacitor energy storage for remote area renewable energy systems, Appl. Energy. 153 (2015) 56-62. doi:10.1016/J.APENERGY.2014.12.008.

[6] N. Sulaiman, M.A. Hannan, A. Mohamed, E.H. Majlan, W.R. Wan Daud, A review on energy management system for fuel cell hybrid electric vehicle: Issues and challenges, Renew. Sustain. Energy Rev. 52 (2015) 802-814. doi:10.1016/J.RSER.2015.07.132.

[7] P. Ball, Y. Gogotsi, Super-capacitors take charge in Germany, MRS Bull. 37 (2012) 802-803. doi:10.1557/mrs.2012.222. 
[8] Y. Ayoubi, M. Elsied, A. Oukaour, H. Chaoui, Y. Slamani, H. Gualous, Four-phase interleaved DC/DC boost converter interfaces for super-capacitors in electric vehicle application based onadvanced sliding mode control design, Electr. Power Syst. Res. 134 (2016) 186-196. doi:10.1016/J.EPSR.2016.01.016.

[9] X. Hu, L. Johannesson, N. Murgovski, B. Egardt, Longevity-conscious dimensioning and power management of the hybrid energy storage system in a fuel cell hybrid electric bus, Appl. Energy. 137 (2015) 913-924. doi:10.1016/j.apenergy.2014.05.013.

[10] X. Zhang, W. Wang, H. He, L. Hua, J. Heng, Optimization of the air-cooled supercapacitor module compartment for an electric bus, Appl. Therm. Eng. 112 (2017) 1297-1304. doi:10.1016/J.APPLTHERMALENG.2016.09.003.

[11] S. Trieste, S. Hmam, J.-C. Olivier, S. Bourguet, L. Loron, Techno-economic optimization of a supercapacitor-based energy storage unit chain: Application on the first quick charge plug-in ferry, Appl. Energy. 153 (2015) 3-14. doi:10.1016/J.APENERGY.2015.04.054.

[12] M. Alamir, M.A. Rahmani, D. Gualino, Constrained control framework for a stand-alone hybrid (Stirling engine)/supercapacitor power generation system, Appl. Energy. 118 (2014) 192-206. doi:10.1016/J.APENERGY.2013.12.044.

[13] G.L. Park, A.I. Schäfer, B.S. Richards, Renewable energy-powered membrane technology: Supercapacitors for buffering resource fluctuations in a wind-powered membrane system for brackish water desalination, Renew. Energy. $50 \quad$ (2013) 126-135. doi:10.1016/J.RENENE.2012.05.026.

[14] H. Gualous, R. Gallay, G. Alcicek, B. Tala-Ighil, A. Oukaour, B. Boudart, P. Makany, Supercapacitor ageing at constant temperature and constant voltage and thermal shock, Microelectron. Reliab. 50 (2010) 1783-1788. doi:10.1016/J.MICROREL.2010.07.144.

[15] D. Torregrossa, M. Paolone, Modelling of current and temperature effects on supercapacitors ageing. Part II: State-of-Health assessment, J. Energy Storage. 5 (2016) 95-101. doi:10.1016/J.EST.2015.11.007.

[16] J. Schiffer, D. Linzen, D.U. Sauer, Heat generation in double layer capacitors, J. Power Sources. 160 (2006) 765-772. doi:10.1016/j.jpowsour.2005.12.070. 
[17] R. Kötz, M. Hahn, R. Gallay, Temperature behavior and impedance fundamentals of $\begin{array}{llllll}\text { supercapacitors, } & \text { J. } & \text { Power } & \text { Sources. } & 154 & \text { (2006) }\end{array}$ doi:10.1016/J.JPOWSOUR.2005.10.048.

[18] M. Al Sakka, H. Gualous, J. Van Mierlo, H. Culcu, Thermal modeling and heat management of supercapacitor modules for vehicle applications, J. Power Sources. 194 (2009) 581-587. doi:10.1016/j.jpowsour.2009.06.038.

[19] Z. Rao, S. Wang, A review of power battery thermal energy management, Renew. Sustain. Energy Rev. 15 (2011) 4554-4571. doi:10.1016/j.rser.2011.07.096.

[20] Q. Wang, B. Jiang, B. Li, Y. Yan, A critical review of thermal management models and solutions of lithium-ion batteries for the development of pure electric vehicles, Renew. Sustain. Energy Rev. 64 (2016) 106-128. doi:10.1016/J.RSER.2016.05.033.

[21] R.D. Jilte, R. Kumar, Numerical investigation on cooling performance of Li-ion battery thermal management system at high galvanostatic discharge, Eng. Sci. Technol. an Int. J. 21 (2018) 957-969. doi:10.1016/J.JESTCH.2018.07.015.

[22] Yunus A. Cengel Afshin J. Ghajar, Heat and Mass Transfer Fundamentals and Applications, Fourth Edi, McGraw Hill Inc., New York, USA, 2011.

[23] T. Wang, K.J. Tseng, J. Zhao, Development of efficient air-cooling strategies for lithium-ion battery module based on empirical heat source model, Appl. Therm. Eng. 90 (2015) 521-529. doi:10.1016/j.applthermaleng.2015.07.033.

[24] J. Zhao, Z. Rao, Y. Huo, X. Liu, Y. Li, Thermal management of cylindrical power battery module for extending the life of new energy electric vehicles, Appl. Therm. Eng. 85 (2015) 3343. doi:10.1016/J.APPLTHERMALENG.2015.04.012.

[25] R. Mahamud, C. Park, Reciprocating air flow for Li-ion battery thermal management to improve temperature uniformity, J. Power Sources. $196 \quad$ (2011) 5685-5696. doi:10.1016/j.jpowsour.2011.02.076.

[26] J. Reyes-Marambio, F. Moser, F. Gana, B. Severino, W.R. Calderón-Muñoz, R. Palma-Behnke, P.A. Estevez, M. Orchard, M. Cortés, A fractal time thermal model for predicting the surface temperature of air-cooled cylindrical Li-ion cells based on experimental measurements, J. 
Power Sources. 306 (2016) 636-645. doi:10.1016/J.JPOWSOUR.2015.12.037.

[27] W.A. Khan, J.R. Culham, M.M. Yovanovich, Convection heat transfer from tube banks in crossflow: Analytical approach, Int. J. Heat Mass Transf. 49 (2006) 4831-4838. doi:10.1016/J.IJHEATMASSTRANSFER.2006.05.042.

[28] H. Gualous, H. Louahlia-Gualous, R. Gallay, A. Miraoui, Supercapacitor Thermal Modeling and Characterization in Transient State for Industrial Applications, IEEE Trans. Ind. Appl. 45 (2009) 1035-1044. doi:10.1109/TIA.2009.2018879.

[29] M. Frivaldsky, J. Cuntala, P. Spanik, Simple and accurate thermal simulation model of supercapacitor suitable for development of module solutions, Int. J. Therm. Sci. 84 (2014) 3447. doi:10.1016/J.IJTHERMALSCI.2014.04.005.

[30] A. Berrueta, I. San Martín, A. Hernández, A. Ursúa, P. Sanchis, Electro-thermal modelling of a supercapacitor and experimental validation, J. Power Sources. 259 (2014) 154-165. doi:10.1016/J.JPOWSOUR.2014.02.089.

[31] A. Hijazi, P. Kreczanik, E. Bideaux, P. Venet, G. Clerc, M. Di Loreto, Thermal Network Model of Supercapacitors Stack, IEEE Trans. Ind. Electron. 59 (2012) 979-987. doi:10.1109/TIE.2011.2158769.

[32] I. Voicu, H. Louahlia, H. Gualous, R. Gallay, Thermal management and forced air-cooling of supercapacitors stack, Appl. Therm. Eng. $85 \quad$ (2015) 89-99. doi:10.1016/j.applthermaleng.2015.04.003.

[33] L. Zhang, X. Hu, Z. Wang, F. Sun, D.G. Dorrell, A review of supercapacitor modeling, estimation, and applications: A control/management perspective, Renew. Sustain. Energy Rev. 81 (2018) 1868-1878. doi:10.1016/J.RSER.2017.05.283.

$[34$

Datasheet K2

utlracapacitors-2.7V

series, n.d. https://www.maxwell.com/images/documents/K2Series_DS_1015370_5_20141104.pdf (accessed December 18, 2018).

[35] R.K. Shah, A.L. London, Laminar flow forced convection in ducts : a source book for compact heat exchanger analytical data, Academic Press, 1978.

[36] S. V. Pantakar, Numerical heat transfer and fluid flow, Hemisphere, Taylor \& Francis Group, 
New York, USA, 1980.

[37] W. Sarwar, M. Marinescu, N. Green, N. Taylor, G. Offer, Electrochemical double layer capacitor electro-thermal modelling, J. Energy Storage. 5 (2016) 10-24. doi:10.1016/J.EST.2015.11.001.

[38] O.S. Burheim, M. Aslan, J.S. Atchison, V. Presser, Thermal conductivity and temperature profiles in carbon electrodes for supercapacitors, J. Power Sources. 246 (2014) 160-166. doi:10.1016/J.JPOWSOUR.2013.06.164.

[39] D.H. Lee, U.S. Kim, C.B. Shin, B.H. Lee, B.W. Kim, Y.-H. Kim, Modelling of the thermal behaviour of an ultracapacitor for a 42-V automotive electrical system, J. Power Sources. 175 (2008) 664-668. doi:10.1016/J.JPOWSOUR.2007.09.081.

[40] H.H. Hauge, V. Presser, O. Burheim, In-situ and ex-situ measurements of thermal conductivity of supercapacitors, Energy. 78 (2014) 373-383. doi:10.1016/J.ENERGY.2014.10.022.

[41] Inc. ANSYS, ANSYS FLUENT Theory Guide, Release 18.2. 15317 (2013) 373-464. doi:10.1016/0140-3664(87)90311-2.

[42] A. Žukauskas, Heat Transfer from Tubes in Crossflow, Adv. Heat Transf. 8 (1972) 93-160. doi:10.1016/S0065-2717(08)70038-8.

[43] L. Davidson, Fluid mechanics, turbulent flow and turbulence modeling, in: Chalmers University of Technology, Göteborg, Sweden, 2018: pp. 175-179. doi:10.1111/j.13653032.2005.00450.x.

Nomenclature

A

$\mathrm{c}_{\mathrm{p}}$

$\mathrm{C}$

$\mathrm{D}$

d

$\mathrm{e}$ surface area

specific heat

supercapacitor capacitance

supercapacitor external diameter

supercapacitor active zone internal diameter

thickness $\mathrm{m}^{2}$

$\mathrm{J} \mathrm{kg}^{-1}{ }^{\circ} \mathrm{C}^{-1}$

F

$\mathrm{m}$

$\mathrm{m}$

$\mathrm{mm}$ 
friction factor

Gr

Grashof number, $=g \beta\left(\mathrm{T}_{\mathrm{s}}-\mathrm{T}_{0}\right) \mathrm{L}_{\mathrm{c}}{ }^{3} / \mathrm{v}^{2}$

$\bar{h}_{c}$

average heat transfer coefficient

$\mathrm{W} \mathrm{m}^{-2}{ }^{\circ} \mathrm{C}^{-1}$

I

Current rate

A

$\mathrm{L}$

supercapacitor length

$\mathrm{m}$

$\mathrm{L}_{\mathrm{c}}$

characteristic length

$\mathrm{m}$

n

number of supercapacitors of the module

$\mathrm{Nu}$

Nusselt number, $=h \times D \times \lambda^{-1}$

$\mathrm{p}$

pressure

$\mathrm{Pa}$

$\mathrm{r}, \mathrm{z}, \theta$

cylindrical coordinates

$\mathrm{Ra}$

Rayleigh number, $=g \times \beta \times\left(T_{S}-T_{0}\right) \times L_{c} \times v^{-1} \times \alpha^{-1}$

$\operatorname{Re}$

Reynols number, $=v_{\max } \times D \times \mu^{-1}$

S

pitch between two consecutive supercapacitors

$\mathrm{m}$

$\dot{Q}$

heat source

W

q

heat source density

$\mathrm{W} \mathrm{m} \mathrm{m}^{-3}$

$\mathrm{T}$

temperature

${ }^{\circ} \mathrm{C}$

$\mathrm{t}$

time

$\mathrm{S}$

$\mathrm{v}$

velocity

$\mathrm{m} \mathrm{s}^{-1}$

$\mathrm{x}, \mathrm{y}, \mathrm{z}$

cartesian coordinates

Greek letters

$\alpha$

thermal diffusivity, $=\lambda \times \rho^{-1} \times c_{p}{ }^{-1}$

$\mathrm{m}^{2} \mathrm{~s}^{-1}$

$\beta$

coefficient of volume expansion

$\mathrm{K}^{-1}$

$\Delta \mathrm{T}$

relative temperature, $=T-T_{0}$

${ }^{\circ} \mathrm{C}$ 


$\begin{array}{ll}\lambda & \text { heat conductivity } \\ \mu & \text { dynamic viscosity } \\ \nu & \text { kinematic viscosity } \\ \rho & \text { density } \\ \text { Subscripts } & \\ \text { b } & \text { supercapacitor central zone, } r<d / 2 \\ \text { D } & \text { diagonal } \\ \text { ext } & \text { external surface of supercapacitor, } r=D / 2 \\ \text { int } & \text { inside the supercapacitor, } r<D / 2 \\ \text { L } & \text { longitudinal } \\ \text { max } & \text { maximum } \\ \text { T } & \text { transversal } \\ 0 & \text { inlet }\end{array}$

$\mathrm{W} \mathrm{m}^{-1}{ }^{\circ} \mathrm{C}^{-1}$

$\mathrm{Kg} \mathrm{m}^{-1} \mathrm{~s}^{-1}$

$\mathrm{m}^{2} \mathrm{~s}^{-1}$

$\mathrm{kg} \mathrm{m}^{-3}$ 